\title{
LingTera
}

Volume 2 - Nomor 1, Mei 2015, (73 - 83)

Available online at LingTera Website: http://journal.uny.ac.id/index.php/ljtp

\section{PENINGKATAN PEMBELAJARAN MENULIS PUISI BEBAS MELALUI MEDIA LAGU MEDLEY SISWA KELAS VIII SMP SINTANG}

\author{
Rohanawati Silalahi ${ }^{1)}$, Haryadi $^{2)}$ \\ SMP Negeri 4 Sintang Kalimantan Barat ${ }^{1)}$, Universitas Negeri Yogyakarta ${ }^{2)}$ \\ rohanasilalahi@ymail.com ${ }^{1)}$,prof_haryadi@yahoo.co.id ${ }^{2)}$
}

\begin{abstract}
Abstrak
Penelitian ini bertujuan untuk meningkatkan pembelajaran menulis puisi bebas melalui media lagu medley siswa kelas VIII B SMP Sintang. Subjek penelitian adalah siswa kelas VIII B SMP Sintang. Penelitian ini merupakan Penelitian Tindakan Kelas (PTK). Prosedur pelaksanaan dan implementasi penelitian dilaksanakan dalam dua siklus. Teknik pengumpulan data berupa obsevasi, wawancara, catatan lapangan, angket, evaluasi dan dokumentasi. Instrumen pengumpulan data meliputi lembar wawancara, lembar catatan lapangan, lembar angket, lembar tes hasil belajar dan lembar portofolio serta dokumentasi foto kegiatan. Teknik analisis data yang digunakan adalah analisis data kuantitatif dan kualitatif. Hasil penelitian ini menunjukkan bahwa penggunaan media lagu medley dapat meningkatkan pembelajaran menulis puisi bebas. Peningkatan hasil atau produk dapat dilihat dari perbandingan skor rata-rata keterampilan menulis puisi bebas siswa pada setiap siklus. Nilai rata-rata siswa pada tahap pratindakan adalah 55,23, pada saat siklus I meningkat menjadi 71,18 , dan pada siklus II meningkat menjadi 73,4.
\end{abstract}

Kata Kunci: menulis puisi bebas, media lagu medley

\section{DEVELOPING THE TEACHING OF FREE VERSE WRITING THROUGH MEDLEY SONG MEDIA TO GRADE VIII STUDENTS OF SMP SINTANG}

\begin{abstract}
This study aims to improve the teaching of free verse writing through medley song media to Grade VIII B students of SMP Sintang. The research subjects were Grade VIII B students of SMP Sintang,. This was a classroom action research (CAR). The research procedure and implementation were conducted in two cycles. The data were collected through observations, field notes, questionnaires, evaluations, and documentations. The data collecting instruments included interview sheets, field note sheets, questionnaire sheets, learning achievement test sheets, portfolio sheets, and documents of activity photographs. The data were analyzed by means of quantitative and qualitative techniques. The results of the study showed that the use of medley song media is capable of improving the teaching of free verse writing. The improvement of the outcome or product is indicated by the comparison of the students' mean score of the free verse writing skill in each cycle. Their mean score in the pre-action stage is 55.23, improving to 71.18 in Cycle I and 73.4 in Cycle II.
\end{abstract}

Keywords: free verse writing, medley song media 


\section{PENDAHULUAN}

Keterampilan berbahasa mencakup empat aspek penting, yaitu (1) keterampilan mendengarkan (listening skills), (2) keterampilan berbicara (speaking skills), (3) keterampilan membaca (reading skills), dan (4) keterampilan menulis (writing skills). Keempat keterampilan tersebut saling berkaitan, tidak dapat dipisahkan. Menulis merupakan satu di antara empat keterampilan yang tidak terpisahkan dalam seluruh proses pembelajaran di sekolah.

Pembelajaran keterampilan menulis memiliki berbagai macam kompetensi. Salah satunya adalah menulis puisi bebas. Hal itu terlihat pada mata pelajaran Bahasa Indonesia SMP/ MTs di kelas VIII Semester 2 dengan standar kompetensi menulis yaitu mengungkapkan pikiran dan perasaan dalam puisi bebas. Kompetensi dasarnya adalah menulis puisi bebas dengan memperhatikan unsur persajakan. Berawal dari hal tersebut, keterampilan menulis puisi bebas merupakan pembelajaran yang harus dikuasai siswa. Pembelajaran menulis puisi bebas tidak hanya dapat mengembangkan kemampuan membuat puisi bebas saja tetapi juga mencermati tema (sense), nada, amanat, bunyi/rima, irama, dan kata yang menarik untuk dibaca.

Berdasarkan hasil survei pratindakan, wawancara dan pengalaman peneliti di kelas VIII SMP Sintang, didapat gambaran mengenai proses pembelajaran menulis puisi bebas sangat rendah. Hal itu terlihat pada gambaran awal kondisi pembelajaran menulis puisi bebas di kelas VIII B yang diketahui bahwa siswa tidak memiliki perhatian dan keaktifan. Siswa cenderung pasif karena tidak memiliki ide untuk menulis puisi bebas. Siswa juga tidak tertarik pada pengajaran penulisan puisi bebas. Siswa tidak mempunyai bekal penguasaan bahasa yang memadai. Menurut siswa pembelajaran menulis puisi bebas itu tidak menyenangkan karena merasa kesulitan merangkaikan kata.

Berdasarkan permasalahan tersebut, timbul keinginan peneliti untuk menerapkan media dalam pembelajaran menulis puisi bebas. Penelitian ini menitikberatkan media lagu medley dalam pembelajaran menulis puisi bebas. Pemilihan lagu medley sebagai media dalam pembelajaran menulis puisi didasarkan pada alasanalasan sebagai berikut: (1) pada usia yang tergolong remaja kebanyakan siswa SMP menyukai lagu, sehingga dengan media ini diharapkan dapat menstimulus siswa untuk menghasilkan karya terbaiknya dan dapat menciptakan suasana belajar yang menyenangkan, (2) lagi pula merupakan sarana hiburan yang menyenangkan dan menciptakan kepuasan, kebahagian dan keharuan bagi yang menikmatinya, (3) dalam lirik lagu terdapat tema (sense), nada, amanat, bunyi/rima, irama, dan kata, melalui lagu dapat mempermudah siswa dalam menulis puisi.

Melalui media lagu medley siswa dapat dengan mudah menulis puisi bebas karena mengaplikasikan penciptaan lagu medley dengan mengambil sepotong-sepotong lagu dengan tema yang sama, dan jenis lagu yang sama, jenis usia yang sama. Sama halnya dengan penciptaan puisi bebas, dengan mengambil lirik dari puisi dengan tema, jenis, dan usia yang sama mengambil sepotong-sepotong. Puisi dapat diambil dari hasil karya sastrawan Indonesia dari berbagai angkatan. Dengan demikian, siswa akan mengenal, membaca, menghargai bahkan mencari buku yang berhubungan dengan puisi atau antologi puisi. Hal ini juga akan merangsang siswa untuk memungsikan perpustakaan. Melalui penggunaan media lagu medley dalam pembelajaran mampu menciptakan suasana yang menyenangkan, membuat pembelajaran menjadi lebih santai, dan pembelajaran akan lebih mudah dipahami oleh siswa. Secara umum, penggunaan media lagu medley diharapkan dapat meningkatkan kemampuan menulis puisi bebas.

Berdasarkan pada latar belakang tersebut, permasalahan yang diangkat pada penelitian ini adalah sebagai berikut, (1) bagaimanakah proses pembelajaran menulis puisi bebas setelah menggunakan media lagu medley?; (2) bagaimanakah hasil pembelajaran menulis puisi bebas setelah menggunakan media lagu medley?

\section{Landasan Teoritis}

\section{Pengertian Menulis}

Lado (1974, p.143) mengatakan, "Learning to write a foreign language is learning to put down at a speed greater than that of drawing the conventional symbols of the writing system that represent the utterances one has in mind'. Pembelajaran menulis adalah menggambar simbol-simbol konvensional yang mewakili ucapan-ucapan yang ada dalam pikiran.

Morsey (dalam Tarigan, 2008, p.20) menjelaskan:Tulisan dipergunakan oleh orang-orang terpelajar untuk merekam, meyakinkan, melaporkan, serta memengaruhi orang lain dan maksud serta tujuan tersebut hanya bisa tercapai dengan baik oleh orang-orang (para penulis) yang dapat menyusun pikirannya serta menguta- 


\section{LingTera, 2 (1), Mei 2015 - 75 \\ Rohanawati Silalahi, Haryadi}

rakannya dengan jelas (mudah dipahami); kejelasan tersebut bergantung pada pikiran, susunan/ organisasi, penggunaan kata-kata dan stuktur kalimat yang cerah.

Menulis merupakan suatu kegiatan dan hasil karya cipta manusia yang lahir dari pikiran-pikiran yang dituangkan ke dalam bentuk tulisan. Tulisan tersebut memiliki makna, tujuan dan merupakan hasil dari kepuasan batin penulisnya dalam menulis. Melalui hasil tulisan dapat terjadi komunikasi antara penulis dengan pembaca. Hal itu dapat terjadi apabila antara penulis dan pembaca masing-masing dapat memahami lambang-lambang grafik atau grafologi yang digunakan dalam tulisan tersebut. Dengan kemampuan penulis memilih unsur-unsur bahasa dalam tulisan, pembaca akan mudah memahami tulisan penulis tersebut. Mengingat hal tersebut, sang penulis dalam kegiatannya harus terampil memanfaatkan grafologi, struktur bahasa, polapola bahasa dan kosa kata. Sebagaimana pendapat tersebut, dalam keterampilan menulis perlu mendapat perhatian yang sungguh-sungguh karena keterampilan menulis bukan keterampilan yang diperoleh secara tradisi melainkan harus dipelajari terlebih dahulu.

Tahap-tahap Menulis

Tahap menulis adalah mulai dari pramenulis, membuat draf, editing, revisi dan publikasi. Pada tahap membuat draf puisi, siswa tinggal mengembangkan kerangka yang sudah dibuat sebelumnya. Tahapan selanjutnya adalah editing. Pada tahap ini, draf yang telah selesai dibaca ulang, Kemudian, kata yang tidak tepat dan tanda baca diberi tanda untuk direvisi. Revisi dilakukan untuk membetulkan tata tulis dan bahasa yang keliru. Tahapan terakhir adalah menuliskan kembali hasil revisi dijadikan karya puisi bebas siap untuk dipublikasikan

\section{Pengertian Puisi}

Muljana (dalam Waluyo, 1987, p.23) mendefinisikan puisi sebagai bentuk sastra dalam pengulangan suara atau kata yang menghasilkan rima, ritma, dan musikalitas. Selain unsur musikal, puisi juga merupakan ekspresi pikiran dan ekspresi perasaan yang bersifat imajinatif. Bahkan aktivitas berpikir dalam puisi merupakan keterlibatan yang sangat tinggi, seperti yang diungkapkan Matheew Arnold (dalam Situmorang, 1993, p.7) "Poetry is the highly organized form of intellectual activity".

Lebih lanjut Matheew Arnold (dalam Situmorang, 1993, pp. 8-9) mengatakan, "puisi adalah satu-satunya cara yang paling indah, impresif, dan yang paling efektif mendendangkan sesuatu". Demikian pula yang dinyatakan oleh John Dryden, "puisi adalah musik yang tersusun rapi". "Puisi adalah nada yang penuh keaslian dan keselarasan" menurut Issac Newton.

Waluyo (1987, p.25) berpendapat: Sebuah puisi adalah sebuah struktur yang terdiri dari unsur-unsur pembangun. Unsur-unsur pembangun tersebut dinyatakan bersifat padu karena tidak bisa berdiri sendiri tanpa mengaitkan unsur yang satu dengan unsur yang lainnya. Unsurunsur dalam puisi bersifat fungsional dalam kesatuannya dan juga bersifat fungsional terhadap unsur lainnya.

Jocson (2011, p.156) seorang guru besar pada Washington University menjelaskan bahwa "Poetry resonates with many individuals in various context; its language exposes socialcrealities that are often steeped in the margins, especially for the young who are frequently attracted to reading and writing it because it is accessible to experimentation in way that prose is not".

Dari beberapa pendapat tersebut dapat dirumuskan bahwa puisi adalah bentuk karangan kesusasteraan yang mengungkapkan pikiran dan perasaan, yang merangsang imajinasi panca indera dalam susunan yang berima, dengan menggunakan unsur musikal yang harmonis sehingga terwujud keindahan. Jadi puisi adalah cetusan perasaan yang paling indah, impresif dan paling efektif dengan medium bahasa yang emosional dan berima.

Unsur-unsur Puisi

Tema

Tema merupakan gagasan pokok atau subject-matter yang dikemukakan oleh penyair. Pokok pikiran atau pokok persoalan itu begitu mendesak dalam jiwa penyair, sehingga menjadi landasan utama pengucapannya

\section{Perasaan (Feeling)}

Perasaan (feeling) merupakan sikap penyair terhadap pokok persoalan yang ditampilkannya. Perasaan penyair dalam puisinya dapat dikenal melalui penggunaan ungkapan-ungkapan yang digunakan dalam puisinya.

\section{Nada dan Suasana}

Nada adalah sikap penyair terhadap para penikmatnya.Nada dalam puisi dapat diketahui dengan memahami apa yang tersurat, bahasa atau ungkapan-ungkapan yang dipakai dalam 


\section{Ling Tera, 2 (1), Mei 2015 - 76 \\ Rohanawati Silalahi, Haryadi}

puisi. Nada berhubungan dengan suasana, karena nada menimbulkan suasana tertentu pada pembacanya. Suasana adalah keadaan jiwa pembaca (sikap pembaca) setelah membaca puisi, atau akibat psikologis yang ditimbulkan puisi terhadap pembaca.

\section{Amanat}

Amanat adalah maksud yang hendak disampaikan atau himbauan, pesan, atau misi yang hendak disampaikan penyair kepada pembaca melalui puisinya.

\section{Diksi (Pilihan Kata)}

Diksi merupakan pilihan kata yang dipergunakan penyair dalam membangun puisinya.

\section{Pengimajian (Imaji)}

Pengimajian adalah pengalaman batin yang pernah dialami kepada para pembacanya dengan pemilihan serta penggunaan kata-kata dalam puisinya. Pengimajian dibatasi dengan pengertian kata atau susunan kata-kata yang dapat mengungkapkan pengalaman sensoris seperti penglihatan, pendengaran, dan perasaan.

\section{Kata Konkret}

Kata konkret adalah arti secara keseluruhan, dengan penggunaan bahasa kiasan dan lambang.

\section{Bahasa Figuratif (Majas)}

Bahasa figuratif adalah bahasa yang digunakan oleh penyair untuk menyatakan sesuatu dengan cara yang tidak biasa, yakni secara tidak langsung mengungkapkan makna kata atau bahasanya bermakna kias atau makna lambang.

\section{Versifikasi (Rima, Ritma, dan Metrum)}

Rima adalah pengulangan bunyi dalam puisi untuk membentuk musikalisasi atau orkestrasi sehingga puisi menjadi menarik untuk dibaca. Ritma adalah pertentangan bunyi, tinggi rendah, panjang pendek, keras lemah, yang mengalun dengan teratur dan berulang-ulang sehingga membentuk keindahan. Metrum adalah nama metrum irama yang berulang secara tetap dan teratur, umpamanya lam baris-baris puisi yang ditentukan oleh jumlah suku kata yang sama.

\section{Tipografi}

Tifografi adalah susunan penulisan dalam puisi Tipografi puisi merupakan bentuk visual yang bisa memberi makna tambahan dan bentuknya bisa dilihat pada puisi konkret. Tipografi bentuknya bermacam-macam antara lain berbentuk garis, kaligrafi, kerucut dan sebagainya. Secara intensional, maksud penyusunan tipografi yang beraneka ragam itu secara garis besar dapat dibedakan menjadi dua macam yaitu (1) sekedar untuk keindahan inderawi, yakni agar susunan puisi tertentu tampak "indah" dipandang (2) untuk mendukung pengedepanan makna, rasa, atau suasana puisi.

\section{Puisi Bebas}

Puisi bebas adalah puisi yang tidak terikat oleh beberapa aturan khusus, yaitu jumlah baris tiap bait, jumlah suku kata tiap baris, sajak, irama, ritma dan pilihan kata. Dalam menulis puisi bebas yang penting perasaan penulis dapat terekspresi dalam bentuk kata-kata yang tepat sehingga menghasilkan makna yang tajam dan mendalam.

Berdasarkan Silabus Pembelajaran Mata Pelajaran Bahasa Indonesia Kelas/Semester VIII (Delapan) / 2 (Dua), standar kompetensi menulis 16 mengungkapkan pikiran dan perasaan dalam puisi bebas dan kompetensi dasar 16.2 Menulis puisi bebas dengan memperhatikan unsur persajakan. Pada kompetensi dasar dinyatakan menulis puisi bebas dengan memperhatikan unsur persajakan. Meskipun telah menggunakan puisi bebas tetapi masih terikat pada unsur persajakan.

Festival Lomba Seni Siswa Nasional (2012, p.10) unsur persajakan adalah sebagai berikut: Tema (sense), Nada, Amanat, Bunyi/ rima, Irama, Kata. Puisi bebas adalah puisi yang tidak terikat oleh beberapa aturan khusus, tetapi tetap memperhatikan unsur persajakan sebagai kriteria penilaian menulis puisi bebas.

\section{Pengertian Media Pembelajaran}

Indriana (2011, p.13) mengatakan, "Media adalah alat saluran komunikasi. Kata media berasal dari bahasa latin, yang merupakan bentuk jamak dari kata medium. Secara harfiah, media berarti perantara, yaitu perantara antara sumber pesan (a source) dengan penerima pesan (a receiver)".

Suryaman (2012, p.123) mengatakan, Secara bahasa, media pembelajaran dapat diartikan sebagai perantara atau pengantar, sedangkan secara tertimologis, media pembelajaran dapat diartikan sebagai seluruh perantara (dalam hal ini bahan atau alat) yang dapat dipakai untuk mencapai tujuan pembelajaran. Misalnya media radio, televisi, buku, majalah, surat kabar, internet, dan sebagainya. 
Media pengajaran adalah bahan, alat, maupun metode/teknik yang digunakan dalam kegiatan belajar mengajar dengan maksud agar proses interaksi komunikasi edukatif antara guru dan anak didik dapat berlangsung secara efektif dan efisien sesuai dengan tujuan pengajaran yang telah dicita-citakan.

\section{Karakteristik Lagu Medley sebagai Media Pembelajaran}

Campbell (2001, p.220) berpendapat bahwa "musik membawa suasana positif dan santai bagi banyak kelas juga memungkinkan integrasi indera yang diperlukan untuk ingatan jangka panjang. Musik berfungsi pula sebagai latar belakang dalam sejumlah ruang kelas meredam bunyi-bunyi industri dan lalulintas, dan musik dapat digunakan secara berhasil menimbulkan kegairahan melepaskan stres sebelum ujian dan memperkuat pokok bahasan". Selanjutnya dalam KBBI (2008, p.771) menyatakan, "Lagu adalah ragam suara yang berirama (dalam bercakap, bernyanyi, membaca, dan sebagainya); nyanyian; ragam nyanyi".

Menurut Kamus Bahasa Inggris On line Lagu medley adalah sebuah komposisi musik yang terdiri dari serangkaian lagu atau potongan musik lainnya dari berbagai sumber (noun communication) komposisi, komposisi musik, opus, sepotong-sepotong music (English Dictionary). In music, a medley is a piece composed from parts of existing pieces, usually three, played one after another, sometimes overlapping. They are common in popular music, and most medleys are songs rather than instrumental. A medley which is a remixed series is called a megamix, often done with tracks for a single artist, or for popular songs from a given year or genre. (Dalam musik, medley adalah bagian terdiri dari bagian-bagian potongan yang ada, biasanya tiga, dimainkan satu demi satu, terkadang tumpang tindih. Hal ini umum pada musik populer, dan sebagian besar adalah lagu medley dan instrumental. Sebuah medley yang merupakan rangkaian remix disebut megamix, sering dilakukan dengan trek untuk artis tunggal, atau lagu-lagu popular dari tahun tertentu atau genre .

Karakteristik lagu medley sebagai media dalam pembelajaran menulis puisi bebas adalah melalui ungkapan lagu yang diberikan lewat lagu medley, lirik atau syairnya adalah serangkaian lagu atau potongan musik lainnya dari berbagai sumber lagu. Sama halnya dengan menulis puisi bebas dengan berbagai sumber karya sastrawan Indonesia yang sudah jadi dan dari berbagai antologi puisi. Potongan-potongan puisi diambil berdasarkan tema dan pilihan kata yang yang sesuai.

Dengan memperdengarkan lagu medley. Siswa menyimak dan memperhatikan lirik-lirik lagu yang ada pada lagu medley. Siswa mengaplikasikan cara membuat lagu medley dengan cara membuat puisi.

\section{METODE}

Subjek penelitian ini adalah siswa kelas VIII B SMP Sintang.Desain penelitian ini setiap siklus tindakannya meliputi perencanaan, melaksanakan tindakan, melakukan observasi dan mengadakan refleksi, serta melakukan rencana ulang.

\section{Jenis Penelitian}

Teknik analisis data yang digunakan dalam penelitian ini ada dua jenis yaitu pertama analisis data kuantitatif dan yang kedua analisis data kualitatif. Data kuantitatif berupa nilai hasil belajar siswa, dianalisis dengan menggunakan deskriptif kuantitatif. Data kuantitatif yang didapat dari hasil tes awal dan tes yang dilakukan setiap akhir tindakan. Hasil tes menulis puisi bebas dibaca kemudian diberi nilai sesuai dengan kriteria pedoman penilaian yang telah dibuat sebelumnya. Hal ini dilakukan agar diketahui nilai rata-rata dan prestasi hasil kerja siswa dan secara tidak langsung akan diketahui besar peningkatan.

Kedua, data kualitatif, berupa informasi deskripsi yang terkait dengan perhatian dan keaktifan siswa, media pembelajaran, evaluasi yang digunakan dalam proses pembelajaran yang meliputi data yang diperoleh melalui observasi, wawancara, catatan lapangan, angket dan hasil evaluasi.

\section{Waktu dan Tempat Penelitian}

Penelitian ini mulai dilaksanakan pada bulan Oktober 2013 sampai dengan bulan November 2013. Penelitian ini dilakukan di SMP Negeri 4 Sintang jalan Mensiku Jaya, Kapuas Kiri Hulu, Sintang Kalimantan Barat. Subjek penelitian ini adalah siswa kelas VIII SMP Sintang.

\section{Prosedur}

Penelitian ini termasuk dalam penelitian tindakan. Variabel dalam penelitian ini adalah objek penelitian atau titik perhatian. Dalam penelitian ini titik perhatian penelitiannya adalah 


\section{Ling Tera, 2 (1), Mei 2015 - 78 \\ Rohanawati Silalahi, Haryadi}

peningkatan pembelajaran Bahasa Indonesia, khususnya peningkatan pembelajaran menulis puisi bebas, melalui media lagu medley siswa kelas VIII SMP Sintang.

Variabel tindakannya yaitu aktivitas siswa dan guru dalam pembelajaran menulis puisi bebas. Penelitian ini akan mengamati situasi pembelajaran yang berlangsung sehingga keberhasilan penelitian akan dilihat berdasarkan adanya peningkatan pembelajaran menulis puisi bebas untuk siswa kelas VIII SMP Sintang

\section{Teknik Analils Data}

Data dalam penelitian ini diperoleh dari siswa dan guru. Data dikumpulkan melalui observasi, wawancara, catatan lapangan, angket (kuesioner), evaluasi (tes menulis puisi), dan dokumentasi.

\section{HASIL DAN PEMBAHASAN}

\section{Peningkatan Pembelajaran Menulis Puisi Bebas melalui Media Lagu Medley}

Pratindakan

Hasil tes pratindakan sebelum d.ilakukan tindakan penelitian sejumlah 21 siswa.hasil tes pratindakan perlu dilakukan untuk mengetahui keadaan awal pembelajaran menulis puisi siswa. Hasil tes pratindakan dapat dilihat pada tabel 1 berikut.

Tabel 1. Penilaian Hasil Penulisan Puisi Bebas (Pratindakan) Siswa Kelas VIII SMP Sintang

\begin{tabular}{lccccccc}
\hline No & Nama Siswa & Kesesuaian isi & Kreativitas & Keunikan & Keindahan & Keberadaan & Nilai \\
(Subjek) 0-21 & $\begin{array}{c}\text { puisi } \\
\text { dengan tema } \\
0-20\end{array}$ & $0-20$ & $0-15$ & $0-20$ & $0-25$ & \\
& & & & & & & \\
1 & Jumlah skor & 270 & 245 & 240 & 230 & 230 & 1215 \\
2 & Rata-rata & 12,27 & 11,14 & 10,91 & 10,45 & 10,45 & 55,23 \\
\hline
\end{tabular}

Hasil tes menulis puisi bebas sebelum tindakan yang diperoleh siswa yaitu nilai tertinggi 72 , nilai terendah 35 , dan nilai rata-rata 55,23 . Nilai rata-rata ini masih jauh di bawah KKM KD (Kriteria Ketuntasan Minimal Kompetensi Dasar) KKM KD menulis puisi bebas adalah sebesar 72 , sedangkan nilai ratarata yang telah diperoleh adalah 55,23.

\section{Siklus I}

Setelah diadakan pembelajaran dengan menggunakan lagu medley pada siklus I pada siswa yang sama menunjukkan hasil seperti pada tabel 2 berikut.

Tabel 2. Penilaian Hasil Pembelajaran Menulis Puisi Bebas (Siklus I) Siswa Kelas VIII B SMP Sintang

\begin{tabular}{cccccccc}
\hline No. & Siswa & $\begin{array}{c}\text { Kesesuaian isi } \\
\text { dengan tema }\end{array}$ & Kreativitas & $\begin{array}{c}\text { Keunikan } \\
\text { puisi }\end{array}$ & Keindahan & $\begin{array}{c}\text { Keberadaan unsur- } \\
\text { unsur puisi }\end{array}$ & Nilai \\
& $0-21$ & $0-20$ & $0-20$ & $0-15$ & $0-20$ & $0-25$ & \\
1 & Jumlah skor & 329 & 334 & 279 & 307 & 312 & 1566 \\
2 & Rata-rata & 14,95 & 15,18 & 12,68 & 13,95 & 14,18 & 71,18 \\
\hline
\end{tabular}

Berdasarkan data pada siklus I terlihat bahwa target belum berhasil karena nilai ratarata masih di bawah KKM (Krieria Ketuntasan Minimal) yaitu 72. Nilai rata-rata pada siklus adalah 71,18. Kriteria keberhasilan sudah terpenuhi, yaitu nilai menulis puisi bebas telah mengalami peningkatan, jika dibandingkan dengan perolehan nilai menulis puisi sebelum dilakukan tindakan. Siswa masih perlu bimbingan sehingga ada peningkatan untuk mencapai nilai rata-rata KKM (Kriteria Ketuntasan Minimal).
Hasil penulisan puisi bebas pada siklus I diketahui bahwa aspek kesesuaian isi dengan tema terlihat sudah baik walaupun masih kurang lengkap. Skor tertinggi 17, ada 1 orang, sedangkan skor terendah 10 , ada 1 orang, sedangkan nilai rata-rata untuk aspek kesesuaian isi dengan tema adalah 14,95 .

Pada aspek kreativitas diketahui kemampuan mengembangkan kata yang imajinatif, kreatif, berjiwa stilistika meliputi: kosa kata, diksi, denotasi, konotasi, bahasa kiasan, citraan (gambaran-gambaran angan) dan gaya bahasa 


\section{LingTera, 2 (1), Mei 2015 - 79 \\ Rohanawati Silalahi, Haryadi}

sudah baik walaupun masih ada yang kurang. Skor tertinggi dalam aspek ini adalah 17, ada 2 orang siswa, sedangkan skor terendah aspek ini adalah 15, ada 20 orang. Nilai rata-rata yang diperoleh pada aspek kreativitas adalah 15,18.

Pada aspek keunikan puisi diketahui siswa memiliki kemampuan dalam menentukan judul yang unik serta menarik masih kurang. Skor yang didapat pada aspek ini tertingginya 17 , ada 2 orang, sedangkan skor terendahnya 10 , ada 2 orang. Nilai rata-rata 12,68.

Pada aspek keindahan diketahui siswa memiliki kemampuan mengembangkan bunyi/ rima yang bersifat estetik, ekspresif, menimbulkan rasa, angan yang jelas dan suasana khusus masih kurang. Skor tertinggi pada aspek ini adalah 17, ada 1 orang, sedangkan skor terendah 10 , ada 5 orang. Nilai rata-rata pada aspek keindahan adalah 13,95.

Pada aspek keberadaan unsur-unsur puisi diketahui siswa belum menunjukkan kemampuan mengembangkan tema (sense), nada, amanat, bunyi/rima, irama, dan kata. Siswa yang mendapatkan skor tertinggi 20, ada 1 orang, sedangkan siswa yang mendapatkan skor terendah 10 , ada 5 Orang. Nilai rata-rata 14,18

Berdasarkan hasil tes pembelajaran menulis puisi bebas siklus I dapat dipaparkan dalam diagram berikut .

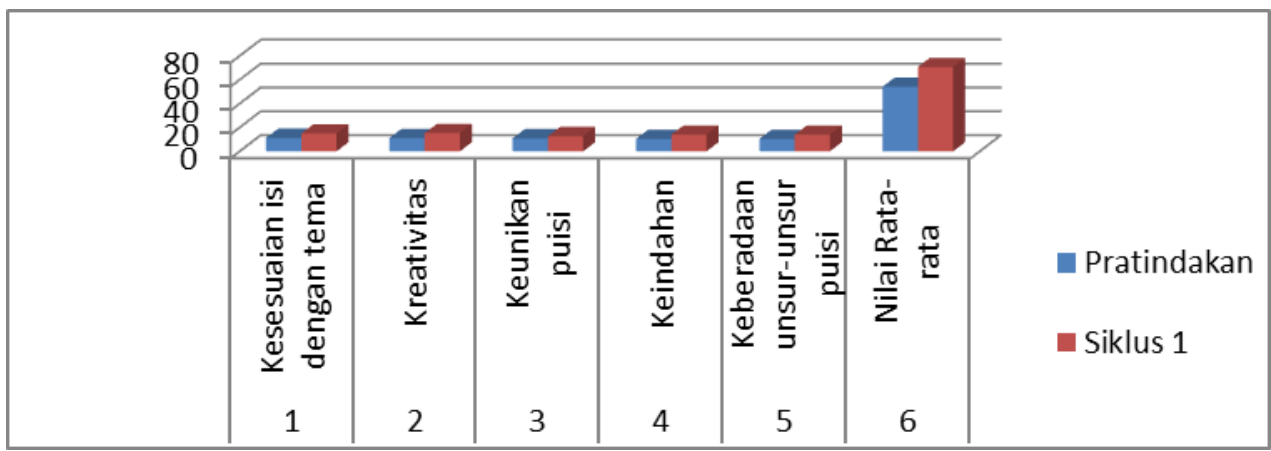

Diagram 1 Hasil Penilaian Menulis Puisi Bebas Pratindakan, Siklus I, dan Siklus II

\section{Proses Pembelajaran}

Observasi

Observasi dalam penelitian ini dilakukan dengan mendokumentasikan pelaksanaan tindakan yang dapat menghasilkan perubahan menuju arah perbaikan. Observasi dilakukan saat pembelajaran menulis puisi bebas mulai dari awal sampai akhir. Observasi dilakukan dengan mengisi lembar chek list observasi yang telah disediakan serta mencatat lembar catatan lapangan yang telah disediakan sebelum penelitian berlangsung.

Hasil observasi saat pelaksanaan menulis puisi bebas menunjukkan bahwa siswa memiliki perhatian dan keaktifan berupa menyimak lagu medley, membuat draf puisi, revisi, menyunting dan publikasi. Perhatian yang dimiliki siswa berupa memperhatikan petunjuk guru, menentukan unsur-unsur puisi yang dilakukan secara individu. Pada tahap membuat draf terlihat perhatian yang dimiliki siswa berupa semangat dalam mengembangkan kerangka puisi, memadukan unsur-unsur puisi dan menuliskan draf. Pada tahap revisi semangat yang dimiliki siswa merevisi pekerjaan sendiri dan membaca kembali draf puisi.
Perhatian yang dimiliki siswa pada tahap pramenulis yaitu siswa memperhatikan petunjuk dan penjelasan guru. Siswa menyimak lagu medley yang bertema cinta yang diperdengarkan sebagai media pembelajaran menulis puisi bebas. Siswa juga memperhatikan pendapat dan kritikan teman dalam membuat kerangka puisi. Pada tahap membuat draf terlihat perhatian yang dimiliki siswa terhadap petunjuk yang diberikan guru, perhatian terhadap kesalahan yang harus direvisi, perhatian terhadap masukan dari teman. Pada tahap menyunting terlihat siswa memiliki perhatian untuk menyunting kesalahan yang ditemukan pada tahap revisi. Siswa melakukan penyuntingan selalu memperhatikan petunjuk penyuntingan yang diberikan guru. Pada tahap publikasi terlihat siswa memiliki perhatian untuk melakukan publikasi hasil karya teman dan hasil karya sendiri.

Keaktifan yang dimiliki siswa dalam tahap pramenulis berupa membuat draf, revisi, menyunting, dan publikasi. Siswa memiliki sikap aktif untuk saling memberikan pendapat pada teman, mengungkapkan ide dalam tahap pramenulis, dan mengungkapkan imajinasi unsur puisi dalam kerangka puisi. Siswa memiliki sikap aktif dan serius dalam mengembangkan 


\section{Ling Tera, 2 (1), Mei 2015 - 80 \\ Rohanawati Silalahi, Haryadi}

ide. Siswa juga aktif dalam membaca hasil karya sendiri. Sikap aktif siswa juga terlihat saat melakukan revisi dengan cermat dan sungguh-sungguh. Pada tahap ini siswa belum meminta tanggapan teman. Siswa memiliki sikap aktif melakukan penyuntingan dengan cermat. Siswa memiliki sikap aktif membacakan karya sendiri dan kooperatif dalam menyimak publikasi yang dilakukan siswa lain.

\section{Siklus II}

Setelah diadakan pembelajaran dengan menggunakan lagu medley pada siklus I pada siswa yang sama menunjukkan hasil seperti pada tabel 3 berikut.

Tabel 3. Penilaian Hasil Pembelajaran Menulis Puisi Bebas (Siklus II)

\begin{tabular}{|c|c|c|c|c|c|c|c|}
\hline \multirow[t]{4}{*}{ No } & \multirow{2}{*}{$\begin{array}{c}\text { Nama } \\
\text { Siswa 0-20 }\end{array}$} & \multicolumn{5}{|c|}{ Aspek } & \multirow[t]{2}{*}{ Nilai } \\
\hline & & $\begin{array}{c}\text { Kesesuaian isi } \\
\text { dengan tema } \\
0-20\end{array}$ & $\begin{array}{c}\text { Kreativitas } \\
0-20\end{array}$ & $\begin{array}{l}\text { Keunikan } \\
\text { puisi } \\
0-15\end{array}$ & $\begin{array}{c}\text { Keindahan } \\
0-20\end{array}$ & $\begin{array}{c}\text { Keberadaan unsur- } \\
\text { unsur puisi } \\
0-25\end{array}$ & \\
\hline & Jumlah skor & 308 & 297 & 286 & 279 & 296 & 1468 \\
\hline & Rata-rata & 15,4 & 14,85 & 14,3 & 13,95 & 14,8 & 73,4 \\
\hline
\end{tabular}

Berdasarkan hasil penulisan puisi bebas pada siklus II diketahui bahwa pada aspek kesesuaian isi dengan tema sudah terpenuhi. Skor tertinggi 18, ada 2 orang, sedangkan skor terendah 10 , ada 1 orang, sedangkan nilai rata-rata untuk aspek kesesuaian isi dengan tema adalah 15,41 .

Pada aspek kreativitas diketahui kemampuan siswa mengembangkan kata imajinatif, kreatif berjiwa atau stilistika antara lain: kosa kata, diksi, denotasi, konotasi, bahasa kiasan, citraan (gambaran-gambaran angan) dan gaya bahasa sudah terpenuhi. Skor tertinggi dalam aspek ini adalah 17, ada 3 orang siswa, sedangkan skor terendah aspek ini adalah 15 , ada 16 orang. Nilai rata-rata yang diperoleh pada aspek kreativitas adalah 15,35.

Pada aspek keunikan puisi diketahui siswa memiliki kemampuan dalam menentukan judul yang unik serta menarik sudah terpenuhi. Skor yang didapat pada aspek ini tertingginya 17, ada 5 orang, sedangkan skor terendahnya 10 , ada 4 orang. Nilai rata-rata 14,30.

Pada aspek keindahan diketahui siswa memiliki kemampuan mengembangkan bunyi/ rima yang bersifat estetik, ekspresif, menimbulkan rasa, angan yang jelas dan suasana khusus masih bertahan. Skor tertinggi pada aspek ini adalah 17, ada 2 orang, sedangkan skor terendah 10 , ada 5 orang. Nilai rata-rata pada aspek keindahan adalah 13,95 .
Pada aspek keberadaan unsur-unsur puisi diketahui kemampuan mengembangkan tema (sense), nada, amanat, bunyi/rima, irama, dan kata sudah terpenuhi. Siswa yang mendapatkan skor tertinggi 17, ada 3 orang, sedangkan sisswa yang nendapatkan skor terendah 10, ada 2 orang. Nilai rata-rata 14,80.

Pada siklus II diketahui penilaian setiap aspek terlihat skor terendah pada aspek kesesuaian isi dengan tema 10, skor terendah pada aspek kreativitas 15, skor terendah pada aspek keunikan puisi 10, skor terendah pada aspek keindahan 10, skor terendah pada aspek keberadaan unsur-unsur puisi 10. Pada siklus II terlihat nilai kesesuaian isi dengan tema masih tetap bertahan, kreativitas, keunikan puisi, keindahan, keberadaan unsur-unsur puisi, ada peningkatan dari siklus sebelumnya. Nilai yang meningkat pada siklus I yaitu nilai rata-rata kesesuaian isi dengan tema 14,95, kreativitas 15,18 , keunikan puisi 12,68, keindahan 13,95, keberadaan unsur-unsur puisi 14,18, sedangkan nilai rata-rata yang diperoleh pada siklus II kesesuaian isi dengan tema adalah 15,40, kreativitas 15,35, keunikan puisi 14,30, keindahan 13,95, keberadaan unsur-unsur puisi, 14,80. Berikut disajikan diagram hasil penilaian menulis puisi bebas pratindakan, siklus I, dan siklus II . 


\section{LingTera, 2 (1), Mei 2015 - 81}

Rohanawati Silalahi, Haryadi

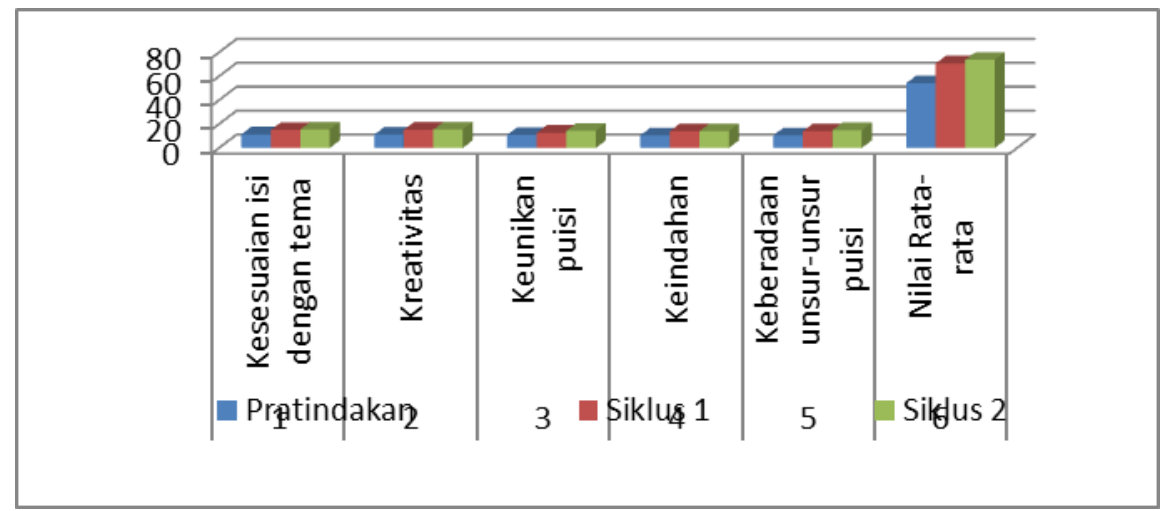

Diagram 2. Hasil Penilaian Menulis Puisi Bebas Pratindakan, Siklus I, dan Siklus II

\section{Proses Pembelajaran}

Observasi

Hasil observasi proses pembelajaran diketahui informasi berupa adanya perhatian. Pada tahap pramenulis diketahui siswa memiliki perhatian terhadap petunjuk dan penjelasan guru, memperhatikan media lagu medley yang digunakan, namun belum memperhatikan pendapat dan kritikan teman dalam membuat kerangka puisi. Pada tahap membuat draf diketahui perhatian terhadap petunjuk yang diberikan guru, saran dari teman dalam membuat kerangka puisi.

Hasil observasi proses pembelajaran terlihat adanya keaktifan yang dimiliki siswa. Pada tahap pramenulis terlihat keaktifan yang dimiliki siswa berupa aktif untuk mengungkapkan ide. Pada tahap membuat draf terlihat keaktifan yang dimiliki siswa adalah serius dalam mengembangkan ide kerangka puisi. Pada tahap revisi terlihat keaktifan yang dimiliki siswa berupa membaca hasil karya sendiri kemudian melakukan revisi. Pada tahap menyunting terlihat keaktifan siswa berupa kegiatan untuk melakukan penyuntingan dengan cermat. Berdasarkan temuan tersebut dapat dikatakan bahwa proses menulis puisi bebas telah mengalami peningkatan.

\section{Pembahasan}

Sebelum tindakan penelitian dilakukan, peneliti mengadakan pratindakan untuk mengetahui gambaran kondisi awal pembelajaran dalam menulis puisi bebas. Setelah diadakan analisis peneliti mengaadakn tindakan. Tindakan yang dilakukan adalah penelitian tindakan kelas. Penelitian tindakan kelas dilakukan dalam dua tahap yaitu siklus I dan siklus II. Lagu medley adalah media dalam meningkatkan pembelajaran menulis puisi bebas. Ketiga hasil tes dapat dilihat pada tabel 4 berikut:

Tabel 4. Hasil Pembelajaran Menulis Puisi Bebas Pratindakan, Siklus I dan Siklus II Siswa Kelas VIII B SMP Sintang

\begin{tabular}{|c|c|c|c|c|c|c|c|}
\hline & & & & Aspel & & & \\
\hline \multirow[t]{2}{*}{ No } & \multirow[t]{2}{*}{$\begin{array}{c}\text { Nama Siswa } \\
0-21\end{array}$} & $\begin{array}{c}\text { Kesesuaian isi } \\
\text { dengan tema }\end{array}$ & Kreativitas & $\begin{array}{l}\text { Keunikan } \\
\text { puisi }\end{array}$ & Keindahan & $\begin{array}{l}\text { Keberadaan unsur- } \\
\text { unsur puisi }\end{array}$ & \multirow[t]{2}{*}{ Nilai } \\
\hline & & $0-20$ & $0-20$ & $0-15$ & $0-20$ & $0-25$ & \\
\hline & Jumlah skor & 270 & 245 & 240 & 230 & 230 & 1215 \\
\hline \multirow[t]{3}{*}{1} & & 329 & 334 & 279 & 307 & 312 & 1566 \\
\hline & & 308 & 297 & 286 & 279 & 296 & 1468 \\
\hline & Rata-rata & 12,27 & 11,14 & 10,91 & 10,45 & 10,45 & 55,23 \\
\hline \multirow[t]{2}{*}{2} & & 14,95 & 15,18 & 12,68 & 13,95 & 14,18 & 71,18 \\
\hline & & 15,4 & 14,85 & 14,3 & 13,95 & 14,8 & 73,4 \\
\hline
\end{tabular}




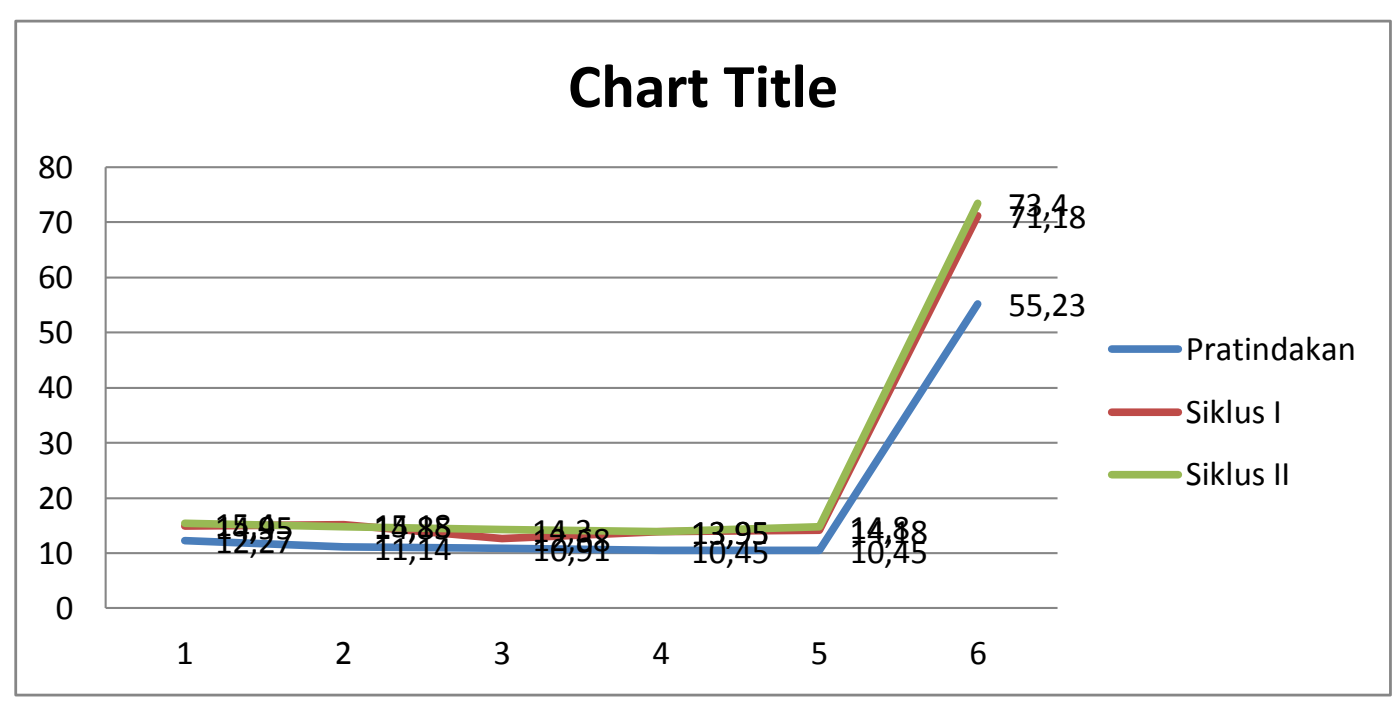

Grafik 1 Peningkatan Pembelajarn Menulis Puisi Bebas

Peningkatan menulis puisi bebas telah tercapai. Nilai yang diperoleh pada siklus II dari setiap aspek telah mengalami peningkatan sebesar 0,$55 ; 0,27 ; 0,85$. Perolehan nilai rata-rata yang diperoleh sebesar 73,8 pada siklus II. Nilai yang diperoleh telah memenuhi Kriteria Ketuntasan Minimal (KKM) yaitu 72. Jadi dapat dikatakan target tercapai dan terjadi peningkatan proses menulis puisi bebas.

\section{SIMPULAN DAN SARAN}

\section{Simpulan}

Pembelajaran menulis puisi bebas dengan menggunakan lagu medley berupa tema cinta dan anak-anak sebagai media pembelajaran mengalami peningkatan pada proses dan hasil pembelajaran. Peningkatan proses menulis puisi bebas ditandai dengan meningkatnya perhatian dan keaktifan siswa dalam setiap tahapan menulis puisi bebas sedangkan peningkatan hasil pembelajaran ditandai dengan meningkatnya aspek kesesuaian isi dengan tema, kreativitas, keunikan puisi, keindahan, keberadaan unsurunsur puisi

Proses pembelajaran menulis puisi bebas pada pratindakan menunjukkan bahwa siswa belum memiliki perhatian dan keaktifan di setiap tahapan menulis puisi bebas. Siswa tidak melakukan tahapan menulis puisi bebas seperti, pramenulis, draf, editing, revisi dan publikasi. Siswa secara langsung menulis dalam bentuk bait dan prosa tanpa memperhatikan aspekaspek yang menjadi penilaian atau kriteria penilaian penulisan puisi bebas yang meliputi kesesuaian isi dengan tema, kreativitas, keunikan puisi, keindahan, keberadaan unsurunsur puisi.
Hasil pembelajaran yang dicapai siswa pada proses pratindakan kurang memuaskan dan belum mencapai target Kriteria Ketuntasan Minimal (KKM) yaitu nilai rata-rata 72. Sebagian tidak memperhatikan aspek-aspek dalam menulis puisi bebas. Pada hasil karya siswa masih ditemukan adanya puisi yang belum diberi judul, dan berbentuk prosa, dan isi pantun. Dilihat dari segi penilaian, siswa masih belum memiliki pemahaman tentang aspek kesesuaian isi dengan tema, kreativitas, keunikan puisi, keindahan, keberadaan unsur-unsur puisi.

Hasil pembelajaran siswa pada siklus I mengalami peningkatan walaupun belum mencapai target Kriteria Ketuntasan Minimal (KKM) yaitu nilai rata-rata 72 . Hasil karya siswa telah menunjukkan peningkatan pada aspek kesesuaian isi dengan tema, kreativitas, keunikan puisi, keindahan, keberadaan unsur-unsur puisi. Siswa sudah menunjukkan kemampuan menulis puisi bebas mengembangkan tema (sense), nada, amanat, bunyi/rima, irama, dan kata. Tapi masih ada siswa yang belum memberi judul dan masih menulis dalam bentuk prosa serta masih banyak coretan sehingga masih diperlukan peningkatan dalam menulis puisi bebas.

Pada siklus II proses pembelajaraan menulis puisi bebas melalui media lagu medley dengan tema anak-anak. Proses pembelajaran menunjukkan siswa memiliki perhatian dan keaktifan dalam menulis puisi bebas. Hasil yang telah dicapai pun mengalami peningkatan dan telah mencapai target Kriteria Ketuntasan Minimal Kompetensi Dasar (KKM KD) yaitu nilai rata-rata 72 . 


\section{Ling Tera, 2 (1), Mei 2015 - 83 \\ Rohanawati Silalahi, Haryadi}

\section{Saran}

Upaya untuk mengatasi kendala yang berkaitan dengan pembelajaran Bahasa Indonesia khususnya pembelajaran menulis puisi bebas, dapat dikemukakan saran sebagai berikut.

Penggunaan media lagu medley dalam pembelajaran Bahasa Indonesia dapat dijadikan salah satu alternatif dalam mengatasi kendala pembelajaran.

Siswa mulai membiasakan diri mengerjakan berbagai tugas keterampilan berbahasa setelah menyimak berbagai lagu medley. Siswa sebaiknya memberikan sikap kooperatif dalam mengikuti kegiatan pembelajaran Bahasa Indonesia khususnya pembelajaran menulis puisi bebas. Siswa sebaiknya dapat menyesuaikan inovasi pengguaan media yang diberikan oleh guru.

\section{DAFTAR PUSTAKA}

Campbell, D. (2001). Efek mozart memenfaatkan kekuatan musik untuk mempertajam pikiran, meningkatkan kreativitas, dan menyehatkan tubuh (terjemahan Termaya). Jakarta: PT Gramedia Pustaka Utama (Buku asli diterbitkan tahun 1997).

Depdikbud. (1988). KBBI. Jakarta: Balai Pustaka

Indriana, D. (2011). Ragam alat bantu media pengajaran.Yogyakarta: DIVA Press
Jocson, K. (2011). "Poetry in a New Race Era". Daedalus; proquest Agriculture Journals. Diakses pada tanggal 21 Maret dari: www.mitpressjournals.org/toc/daed/140/1

Kamus Bahasa Inggris Online - Kamus Inggris Indonesia. (2014). Kamus online Indonesia-Inggris. Diambil pada tanggal 14 April 2014 dari: http://www.artikata.com/arti-346320puisi.html

Kemendikbud. (2012). Pedoman FLS2N (festival Lomba Seni Siswa Nasional. Jakarta: Kemendikbud

Lado, R. (1974). Language teaching. NewYork: Macmillan Publising Company.

Pusat Kurikulum. (2006). Standar kompetensi dan kompetensi dasar mata pelajaran bahasa Indonesia. Jakarta: Purkurbuk

Situmorang, B. P. (1993). Puisi dan metodologi pengajarannya. Flores: Nusa Indah.

Suryaman, M. (2012). Metodologi pembelajaran bahasa.Yogyakarta: UNY Press

Tarigan, H. G. (2008). Menulis sebagai suatu keterampilan berbahasa. Bandung: Angkasa.

Waluyo, H. J. (1987). Teori dan apresiasi puisi. Jakarta: Erlangga 